\title{
Status Quo of Glycosylation in Cancer: What Is, What Is Not and What Is to Be
}

\author{
Manikandan Muthu ${ }^{1}$, Judy Gopal ${ }^{1}$, Sechul Chun ${ }^{1}{ }^{1}$, Anna Jacintha Prameela Devadoss ${ }^{2}$ \\ and Jae-Wook $\mathrm{Oh}^{3, *(\mathbb{D})}$ \\ 1 Department of Environmental Health Sciences, Konkuk University, Seoul 143-701, Korea; \\ bhagatmani@konkuk.ac.kr (M.M.); judygopal@konkuk.ac.kr (J.G.); scchun@konkuk.ac.kr (S.C.) \\ 2 Faculty of Biology, New Prince Shri Bhavani Senior Secondary School, Ullagaram, Chennai 600091, India; \\ anna@konkuk.ac.kr \\ 3 Department of Stem Cell and Regenerative Biotechnology, Konkuk University, Seoul 143-701, Korea \\ * Correspondence: ohjw@konkuk.ac.kr; Tel.: +82-2-2049-6271; Fax: +82-2-455-1044
}

Received: 26 October 2020; Accepted: 19 November 2020; Published: 25 November 2020

\begin{abstract}
Glycobiology is gaining paramount importance for its influence on diseases as a consequence of a fundamental understanding of the underlying processes involved in them. Cancer is still posing threats to human health and welfare and therapies are perpetually being sought. Glycans are selectively attached to proteins and lipids during glycosylation, and these hold anchorage positions in many important biological processes involved in cancer through their altered expression or activity upon malignant transformation. Aberrant glycosylation is well established as a hallmark of cancer, linked to tumor development and metastasis. The analytical inputs and milestones achieved and the characterization and detection of glycosylation in cancer have been summarized in this review. The milestones achieved in cancer research through inputs from glycosylation have been highlighted. With almost $70 \%$ of biopharmaceuticals being glycoproteins and almost $80 \%$ of cancer biomarkers being glycan in origin, glycosylation has a lot of say in cancer prognosis and diagnosis. The future of glycosylation in cancer and the lacunae in the smooth channelization of state-of-the-art technologies for taking this research knowledge from bench top to bedside (actual clinical settings) is speculated upon. The incorporation of cross-disciplinary integrated approaches and nano-instrumentation sophistications are proposed for achieving scaling up.
\end{abstract}

Keywords: cancer; glycobiology; biomarkers; aberrant glycosylation; analytical instrumentation

\section{Introduction}

Cancer is the second most common cause of mortality in developed countries. The reason for the high mortality is that mostly cancers are discovered at advanced stages [1-3]. Enhanced survival rates depend on early detection and delayed detection can have serious consequences. Owing to the absence of early symptoms and inhibition to seek medical investigation, most cases are diagnosed very late $[4,5]$. Survival rate depends on the stage when the disease is initially diagnosed. Early diagnosis and the inclusion of minimally invasive screening methods are crucial for enhancing the survival rates of cancer patients. Biomarkers are reported as an alternative/complementary strategy to histopathology or imaging techniques, providing minimally invasive predictive information [6]. In addition to these, novel biomarkers with superior diagnostic and prognostic characteristics are also in play.

Carbohydrates were considered as mere metabolites with no significant functionality. A paradigm shift is said to have occurred in the 20th century, when the action of a lectin, ricin from castor beans, was discovered to bring about agglutination of red blood cells [7]. Nowadays, it is established that other than immunogenicity, carbohydrates also impart crucial functions on the biomolecules 
they are attached to. Glycosylation is an essential co- and post-translational modification (PTM) occurring in cells. Glycans, carbohydrate molecules, are selectively attached to proteins and lipids during glycosylation, exhibiting control over protein folding and clearance rates, inflammation and metastasis, while functioning as biomarkers of diseases [8]. Glycosylation is involved in cell signaling, immune recognition and cell-cell interaction and plays a key role in cancer-related aspects such as cell adhesion, cell signaling, migration, interactions with the cell matrix, immune surveillance and cellular metabolism. Glycan modifications in cells or tissues take place through the synchronized action of numerous glycosylation enzymes inside the Golgi and the endoplasmic reticulum. Glycans are linked to lipids and proteins through two mechanisms namely $\mathrm{O}$ - and $\mathrm{N}$-linked glycosylation [9-11].

The synthesis of aberrant glycan chains is now an established hallmark of cancer. This is a consequence of distinct alterations in the microenvironment-metabolism and in glycoprocessing enzymes [12]. These aberrations become more apparent as the tumor becomes more aggressive and translate to function as biomarkers of the disease. In this way, aberrant protein glycosylation has now become a promising source of glycobiomarkers for diagnosis and prognosis. Glycoproteins enter the circulatory system through leakage, rendering serum as a biomarker pool from a diagnostic perspective. A lot more prospective developments leading to cancer vaccines is also anticipated as a challenging perspective.

The existence of complex truncated or novel glycan structures influences ligand-receptor interactions. This further interferes with the regulation of various biological processes in the cell. Aberrant glycosylation, thus reflects cancer-inflicted alterations in glycan biosynthesis. This is rendered possible through altered expression of glycosyltransferases, glycosidases, fucosylation and sialylation. Being able to distinguish differences in the glycosylation of proteins within cancer and controls, glycobiology is established as a potential biomarker identifier [13].

This review highlights the achievements of glycosylation in cancer, diagnosis, prognosis and therapy. The analytical inputs for cancer diagnosis in the area of glycosylation and the progress from glycan-based cancer biomarkers have been summarized. The challenges against the progress of glycosylation in cancer research have been speculated upon and the future goals for exponential application-based upgrades discussed.

\section{Milestones of Glycosylation in Cancer}

\subsection{Analytical Milestones on Glycosylation for Cancer}

Conventional methods like lectin histochemistry, like traditional immunohistochemistry, have been proven as the established method for glycobiomarker identification [14]. Both techniques have been popularly used to study glycoconjugates involved in progression and metastasis of cancer. These classical methods have been successful in analyzing glycan biomarkers. However, they have limited scope when it comes to large-scale applications and are unable to cope with the developments in genomics and proteomics.

Wang et al., 2019 have elaborately reviewed analytical inputs in glycomics-based biomarker studies using: mass spectrometry (MS), capillary electrophoresis (CE), high-performance liquid chromatography (HPLC), ultra-performance liquid chromatography (UPLC) and liquid chromatography (LC-MS) [14]. We briefly present the milestones achieved in glycosylation in cancer diagnosis and prognosis through the use of these state-of-the-art technologies. LC-MS has been reported as being used to evaluate the changes in glycoproteins in the serum of cancer patients: $\alpha 1$-antitrypsin (A1AT) [15], $\alpha 1$-acid glycoprotein [16], haptoglobin (Hp) [17-19] and immunoglobulin $\mathrm{G}(\mathrm{IgG})[20]$. These altered glycosylations can be correlated with cancer progression. Glycan separation prior to MS analysis, is achieved using LC coupled with MS for the characterization of the entire glycome. Hydrophilic interaction chromatography (HILIC)-LC, reverse phase (RP)-LC and porous graphitized carbon (PGC)-LC have been successfully used. Lubman et al., detected fucosylated $\mathrm{N}$-glycan structures to be upregulated in hepatocellular carcinoma (HCC) in serum Hp using the 
HILIC-LC-MS method [21]. The same group also detected core fucosylation (CF) levels in serum $\alpha 2$-macroglobulin (A2MG) [22] and serum ceruloplasmin (CP) [23] using RP-LC-MS/MS, differentiating between HCC and cirrhosis patients. Iliopoulos et al., using RP-LC-MS/MS, evaluated the site-specific $\mathrm{N}$-glycan changes in renal carcinoma patients prior to and subsequent to nephrectomy [24]. Using PGC-LC- tandem mass spectrometry (PGC-LC-MS/MS), Lebrilla et al., identified and determined the relative abundance of $\mathrm{N}$-glycans released from human serum [25]. Rudd et al., characterized the total serum N-glycans from advanced breast cancer patients using HPLC coupled with MS. They proved that there was a distinct increase in the sialyl-Lewis X epitope (CESLEX). The sialyl-Lewis $X$ epitope is reported to be a better indicator for breast cancer than the currently used biomarker, CA15-3, since CA15-3 is not a standalone marker [26]. CESLEX in combination with CA15-3 is reported to be useful for monitoring breast cancer patients. The Li group reported the use of HILIC-LC-MS for quantification of N-glycans in human serum proteins. This significantly improved quantification of the N-glycome compared to the existing traditional quantification methods, making it feasible for quantitative glycomics analysis for biomarker discovery [27]. A novel antibody microarray was used to analyze cancer-related epitopes sLex and sLea in the serum of colon cancer patients [28]. LC-MS determined site specific -linked oligosaccharide alterations in oesophageal cancers [29]. HPLC-based analysis of serum glycosylation revealed differences in fucosylation and sialylation in prostate cancer patients [30]. These alterations in serum glycosylation have been used to differentiate different stages of prostate cancer.

Using only $10 \mu \mathrm{L}$ of patient serum employing quantitative matrix assisted laser desorption/ionization-quadrupole ion trap mass spectrometry (MALDI-QITMS/MS), the Lubman group reported elevated fucosylated N-glycans in Hp in pancreatic cancer [31]. They also found a distinct bi-fucosylated tetra-antennary N-glycan in HCC patients, which outperformed alpha-fetoprotein (AFP) in differentiating HCC from cirrhosis [31]. Nakagawa et al., used MALDI- time of flight-MS (MALDI-TOF-MS) to detect N-glycan structures of AFP in HCC patients [32]. The Rudd group combined HILIC-UPLC with capillary electrophoresis-laser-induced fluorescence (CE-LIF) for characterizing $\mathrm{N}$-glycan serum samples rapidly within $20 \mathrm{~min}$ [33]. The same group used HILIC-UPLC, assigning $140 \mathrm{~N}$-glycans in human serum. They reported that increased sialylation, branching, and outer-arm fucosylation and decreased high-mannosylated and bi-antennary core-fucosylated glycans could help in identifying breast cancer patients from normal patients [34]. Knezevic et al. designed a UPLC method that analyzed 864 plasma samples per day, facilitating serum-based glyco-biomarker discovery [35]. An alternative $\mathrm{N}$-glycomic profiler combined DNA sequencer method was developed by Callewaert et al. [36,37], for characterizing 9-aminopyrene-1,4,6-trisulfonic acid (APTS) labeled $\mathrm{N}$-glycome in bio-fluids [38-40] and purified proteins [41]. Gao et al., modified this method to study the N-glycan-based biomarkers in HCC, CRC, multiple myeloma, gastric cancer and extrahepatic cholangiocarcinoma [42-46]. They have constructed diagnostic models for the same. Several analytical techniques based on lectins including lectin blot $[47,48]$ lectin histochemistry/cytochemisty $[49,50]$, lectin-antibody sandwich enzyme-linked immunosorbent assay (ELISA) [51-53], lectin affinity chromatography [54,55], lectin microarray [56-58] and lectin microfluidics [59] have been used to capture specific glycans of glycoproteins [56,60-62]. The Gao group analyzed the diagnostic and prognostic application of fucosylated fetuin A in HCC patients using aleuria aurantia lectin (AAL)-based ELISA [63]. The Lubman group reported abnormal sialylation levels in the serum of ovarian cancer patients using sambucus nigra lectin (SNA)-based ELISA [64] and using reverse AAL-based ELISA, Lubman et al., evaluated fucosylated Hp combined CA125 in ovarian cancers, to distinguish early-stage ovarian cancer [53]. This was more accurate than CA 125 standalone. This is a brief overview of the cancer milestones attained availing of the various analytical expertise available. It is evident that the reported analytical techniques have impacted this area of research significantly and have led to noteworthy achievements. Figure 1 gives an overall outlook of the mass spectrometry-based variants that have been used for biomarker analysis. 


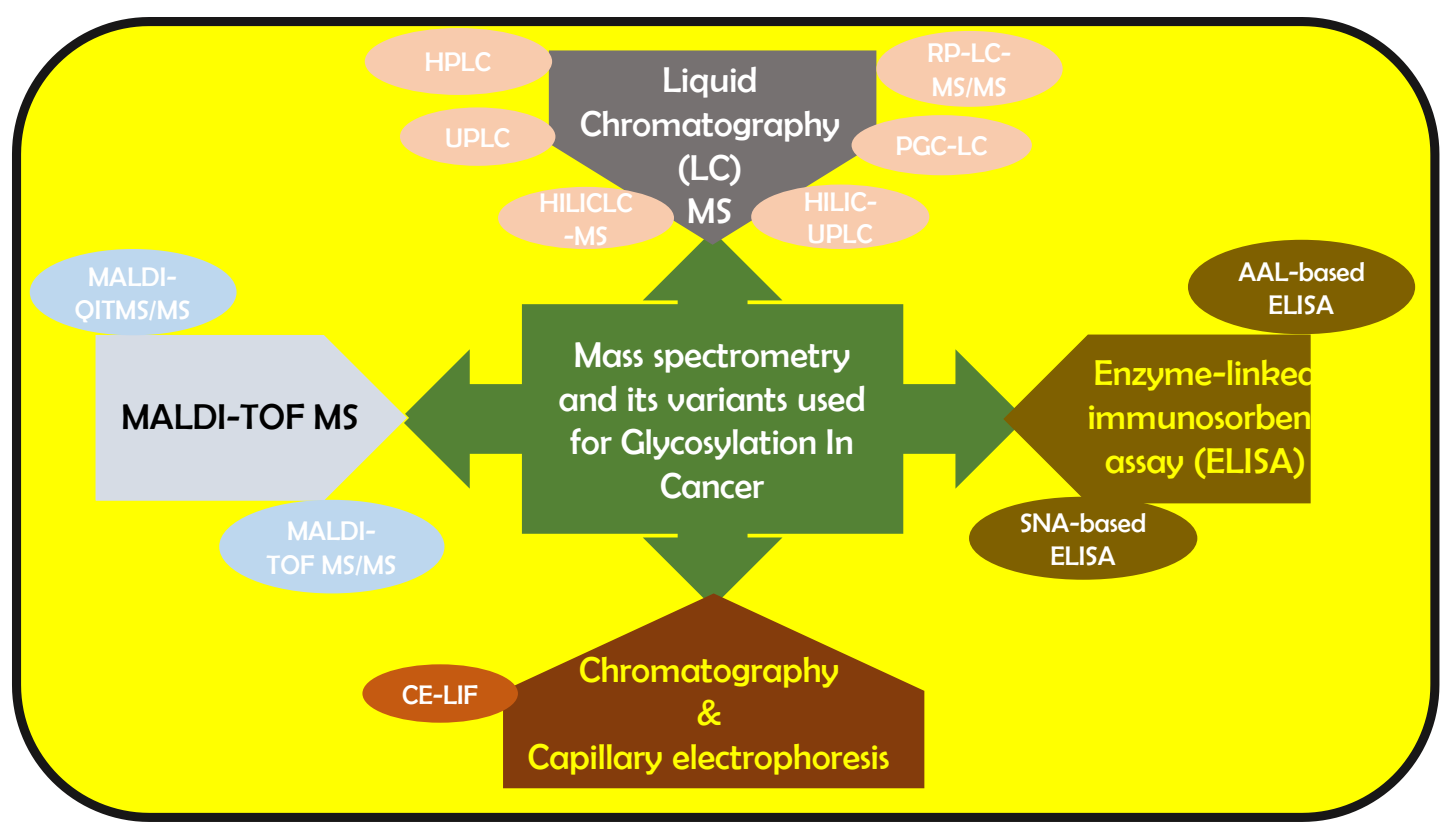

Figure 1. Mass spectrometry and its variants that have been reported to be used to analyze glycan-based cancer biomarkers.

\subsection{Glycosylation for Cancer Biomarkers}

Cellular glycosylation is coordinated by glycosyltransferases and glycosidases to bring about addition/modification of glycans on proteins and lipids [65]. Glycomics unravels the impact of glycosylation in cancer [66-68]. Enzymes may be altered because of cancer and can be linked to tumor development. 1-6-N-acetyl-glucosaminyltransferase (GnT-V) is overexpressed in various cancers and is interconnected with higher invasive potential [69], metastasis [70], vascular remodeling [71] and tumor growth [72]. Biomarkers that can result in early diagnosis and can be used to design new therapeutic strategies are now needed. This has been accomplished by targeting cancer-associated glycans.

Munkley et al., in their exhaustive and excellent review have elaborately discussed how aberrant glycosylation is closely interrelated with protein glycoforms which can be used as cancer biomarkers [73]. Aberrant glycosylation is reported to play a key role in cancer progression according to Munkley and Elliott, 2016. The same group has also documented the initiation and progression of cancer bringing about fundamental changes in the glycome [74]. Munkley et al. 2016 have reported aberrant glycosylation and have established the link between aberrant glycan composition of prostate cancer cells and disease progression [74]. Glycosylation is reported as the global target for androgen control in the case of patients suffering from prostate cancer. Aberrant CD43 has been established as a cancer biomarker. UN1 monoclonal antibodies (UN1 $\mathrm{mAb}$ ) have been reported to be able to identify aberrant CD43 glycoforms [75]. Serological assays in clinical practices detect and quantify glycans in cancer patient's serum. Circulating glycoconjugates are used for diagnosis, therapy monitoring, detecting disease recurrence and prognosis. Glycoconjugates, such as sialyl-Lewis A (SLea) (CA19-9), STn (sialyl Tn) (CA72-4) and mucin glycoproteins MUC1 (CA15-3) and MUC16 (CA125) [76-79], are crucial serum cancer markers. CA125, a transmembrane mucin, is currently the best biomarker for ovarian cancer. Elevated levels of CA125 have been reported in the serum of stage I ovarian cancer patients, 60 months prior to actual diagnosis [80]. High CA125 serum levels have been reported in about $80 \%$ of epithelial ovarian cancer patients $[78,81]$. CA125 preoperative levels help in the prognosis of ovarian cancer patients, relating to the progression or regression of cancer in the system. CA125 is also ideal for monitoring chemotherapy responses, detecting recurrence and for prognosis [82-84]. MUC1 is also a transmembrane mucin overexpressed in $90 \%$ of breast cancers, and it is evaluated using the CA15-3 assay. CA15-3 is useful in understanding response to anticancer therapy, and prognosis for breast cancer [85-88]. Increase in CA15-3 prior to treatment can be correlated with inadequate prognosis, 
pointing out a failure in treatment $[85,89]$. The CA19-9 assay detects sLeA in colorectal, gastric, pancreatic or biliary cancer patients, and it is most sensitive and specific with respect to pancreatic cancer $[90,91]$. In the case of colon cancer, patients with high CA19-9 are reported to have a four times greater mortality rate than those with lower. In gastric cancer, prior to surgery CA 19-9 behaves as a prognostic marker and for risk factor assessment for the relapse of gastric carcinoma [92-95]. The CA72-4 assay detects aberrant sialyl-Tn (STn) in the serum of patients with gastric, colorectal, pancreatic, lung and breast carcinomas [92,96-101]. CA72-4, is reported for its role as an independent prognostic factor in gastric carcinoma and in pancreatic cancer [102,103]. Carcinoembryonic antigen (CEA), is a member of a family of $\mathrm{N}$-glycoproteins, its serum levels act as a marker for a wide range of human carcinomas [104-108]. Tuccillo et al. have published an overview of the glycosylation-linked biomarkers in their detailed review [75].

Pancreatic adenocarcinoma is a deadly form of cancer with a 5-year survival rate of $<5 \%$. Its diagnosis consists of imaging and tissue biopsy and complete surgical resection is the only curative therapy. Pancreatic cancer metastasizes early and mostly patients are diagnosed when treatment is not possible. Carbohydrate antigen CA 19-9, sLeA is the most established biomarker for this form of cancer. Other markers include truncated O-glycans (Tn and sTn), elevated sialyl Lewis $X$ antigen (sLex), branched and fucosylated N-glycans, upregulated proteoglycans and galectins and elevated O-GlcNAcylation [109]. Glycosylation is reported to be instrumental for androgen control in prostate cancer cells. Eight glycosylation enzymes (GALNT7, UAP1, GCNT1, PGM3, ST6GalNAc1, ST6GAL1, CSGALNACT1 and EDEM3) are significantly upregulated in prostate cancer. These 8 enzymes are under an androgen receptor (AR) and are reported by Munkley to be linked to cancer-related sialyl-Tn (sTn), sialyl LewisX (SLeX), O-GlcNAc and chondroitin sulfate. AR as well as glycosylation is reported to be mediated by androgens in prostate cancer cells [110]. Importantly, AR regulates key glycosylation enzymes and synthesis of several cancer-linked glycans in prostate cancer [111]. Epithelial ovarian malignancy is the fifth most common disease in women, having the highest death rate. The membrane glycosylation of non-carcinogenic ovarian surface epithelial (HOSE 6.3 and HOSE 17.1) and serous ovarian disease cell lines (SKOV 3, IGROV1, A2780, OVCAR 3), have been contemplated. Proof has been published [112] that MGAT3 articulation might be epigenetically controlled by DNA hypomethylation, bringing about the one of a kind "bisecting GlcNAc" type $\mathrm{N}$-glycans on the membrane proteins of ovarian cancer cells. Glycoenzymes as a therapeutics target for cancer patients are also under consideration [113] Glycoproteins comprise of protein tumor markers endorsed by the Food and Drug Administration (FDA), and are being applied into clinical practices. The FDA endorsed biomarkers include: MUC-1 (CA15-3/CA27.29) [114] and plasminogen activator inhibitor (PAI-1) [115], beta-human chorionic gonadotropin (Beta-hCG) [116], the biomarker of breast cancer; AFP; biomarkers of colorectal cancer [117], biomarkers of liver cancer and germ cell cancer, chromogranin A (CgA) [118], biomarkers of neuroendocrine cancer and MUC16 (CA-125) [119] and HE4 [120], biomarkers of ovarian cancer [121].

The molecular evidence of aberrant glycosylation in colorectal cancers (CRC) was explored. Venkitachalam et al., focused on re-sequencing of 430 glycosylation-related genes in patient-derived CRC cell lines and matched primary tumor tissues. They reported changes in 12 new glycosylation-related genes in colon disease [122]. Enrichment of mutations in B3GNT2, B4GALT2, ST6GALNAC2 genes associated with the biosynthesis of N-and O-linked glycans in the colon was reported. They concluded that deleterious mutations in glycosyltransferase genes are linked to aberrant glycosylation and impact on colon and other gastrointestinal cancers.

It is accepted that the acknowledgment of the widespread pertinence of glycosylation to the cancer hallmarks will progressively affect disease treatment through the advancement of new efforts to treat cancer [123]. At present, most cancer treatment protocols include radiotherapy, medical procedures, and chemotherapy. Endeavors are in progress for recognizing compelling cutting edge therapies to supplant conventional strategies $[124,125]$. Production of anticancer therapeutic proteins as a class of medications is dominant in the medication business, due to advances in recombinant DNA 
innovation [126]. Glycosylation plays a crucial role in recombinant anticancer therapeutic proteins, as most of the approved recombinant therapeutics are glycoproteins. Various methodologies have been adopted to design the Golgi's N-glycosylation pathway to obtain human-like glycans. Several researchers have attempted to design the $\mathrm{N}$-glycosylation pathway of expression systems. Among the total endorsed biopharmaceuticals, practically $70 \%$ are glycoproteins [127-130]. Numerous functions of anticancer glycoproteins are related to solubility, pharmacodistribution, pharmacokinetics, proper structural folding, binding to receptors and serum half-life of glycans [131]. The most noteworthy anticancer therapeutic recombinant proteins are mAbs, which are glycosylated in their Fc area [132].

The glycocalyx is said to drive the interaction between malignant cells and the tumor microenvironment (TME). Both glycans, glycoconjugates and the TME effectively add to cancer hallmarks, by affecting various interactions $[11,133,134]$. Generally, the crosstalk between neoplastic cells and the TME guarantees smooth progress of the associated processes. Glycosylation generally impacts the extrinsic apoptotic process including both TNF-Related Apoptosis Inducing Ligand (TRAIL) and Fas passing receptors, just as integrin and galectin-mediated signaling. Glycans, glycosyltransferases, and glycosidases assume significant functions in apoptosis [135] by thwarting ligand-receptor interactions $[135,136]$. The tumor necrosis factor (TNT)-related apoptosis-inducing ligand (Apo2L/TRAIL) advances tumor cell apoptosis through TRAIL-R1 and TRAIL-R2, whose O-glycosylation status decides its sensitivity to the ligand. In particular, GALNT14 shows a strong link to TRAIL sensitivity in pancreatic cancer, non-small-cell lung carcinoma (NSCLC) and melanoma. The expression of GALNT3 and O-glycan processing enzymes FUT3 and FUT6 is unique in CCCs. This information is useful in recognizing cancer patients who are bound to react to TRAIL-based therapies [136]. Furthermore, a lower degree of fucosylation, due to mutation of GDP-mannose-4-6-dehydratase (GMDS), expands the resistance from TRAIL-initiated apoptosis in CCC [137]. N-glycosylation has a regulatory function in TRAIL-R1-mediated apoptosis, yet not in TRAIL-R2 (without N-glycans). Defective apoptotic signaling by N-glycan-deficient TRAIL receptors is related to lower TRAIL receptor aggregation and reduced death inducing signaling complex (DISC) formation, without diminished TRAIL-binding affinity [138]. In addition, the death receptor Fas (CD95/APO-1) has two N glycosylation sites at N136 and N118 modestly influencing Fas induced apoptosis. The addition of sialic acids by ST6Gal-I in a $\alpha 2-6$ linkage to the N-glycans of Fas provides security against Fas-induced apoptosis in CCCs. Specifically, $\alpha 2-6$ sialylation of Fas hinders FasL-induced apoptosis, blockage of Fas-Fas-associated death domain (FADD) association with Fas cytoplasmic tails and inhibition of Fas internalization [139-141]. Also, N-deglycosylation of Fas prompts the slowing down of procaspase-8 activation at the DISC complex, with no effect on DISC formation or FADD recruitment [142].

Glycosyltransferases, otherwise called N-acetyl galactosaminyltransferase 1 (GALNT1), are reported to activate survival signals that stifle apoptosis. In particular, overexpression of $\mathrm{N}$ acetyl galactosaminyltransferase 1 (GALNT1) adds to aberrant glycosylation of integrin $\alpha 3 \beta 1$, changing the conformation of integrin heterodimers and promoting signal transduction to incite focal adhesion kinase (FAK) activation in bladder cancer cells [143]. Another significant molecular mechanism is the crosstalk among lectins and death receptors. Traditionally, the impact of galectin-3 (Gal-3) in apoptosis relies upon its subcellular localization [144-147]. O-6-sialylation of integrin $\beta 1 \mathrm{~N}$-glycans, mediated by ST6Gal-I, totally impeded its recognition by Gal-3; then again, O-3-sialylation did not influence Gal-3 recognition in gastric cancer $[144,148]$. These perceptions unequivocally demonstrate that Gal-3 binding to glycans is dependent on sialylation. Unraveling the sialome of cancer cells is expected to give new insights on programmed cell death pathways.

The hyperglycosylated form of hCG is expressed by several tumors, like male germ cell tumors (GCTs) and choriocarcinomas [149,150]. It also influences cancer invasion [151]. High concentrations of hCG indicate adverse prognosis $[149,150]$. A1AT is a $52 \mathrm{kDa}$ serine protease inhibitor with three glycosylation sites brought forth by hepatocytes and is upregulated in the serum of lung cancer patients [152-155]. Fucosylated haptoglobin (Fuc-Hpt) has been recognized as a promising biomarker 
in pancreatic cancer [156] and found to be upregulated in pancreatic cancer patient's sera [157]. YKL-40, also known as chitinase-3-like 1 (CHI3L1) or human cartilage glycoprotein-39, is a $40 \mathrm{kDa}$ secreted glycoprotein, which is also a biomarker (that has not received FDA approval) [158]. YKL-40 was reported as a prognostic biomarker in multiple myeloma (MM) [159]. Alpha-1-acid glycoprotein (AGP), a $40 \mathrm{kDa}$ acute phase serum glycoprotein is reported to impact different cancers [160]. Peixotol et al., have recently published a detailed review on the influence of protein glycosylation and tumor microenvironments in driving cancer hallmarks [161].

NCT00460356 is one of the clinical trials ongoing for using the glycosylation-related knowledge in real time [162]. NCT00897962, NCT00897962 and NCT00628654 are the other ongoing clinical trials. Other than these clinical trials, not much technology transfer has been made in this direction Figure 2 gives an overview of the interlinking factors between glycosylation (aberrant glycosylation) and cancer [162].

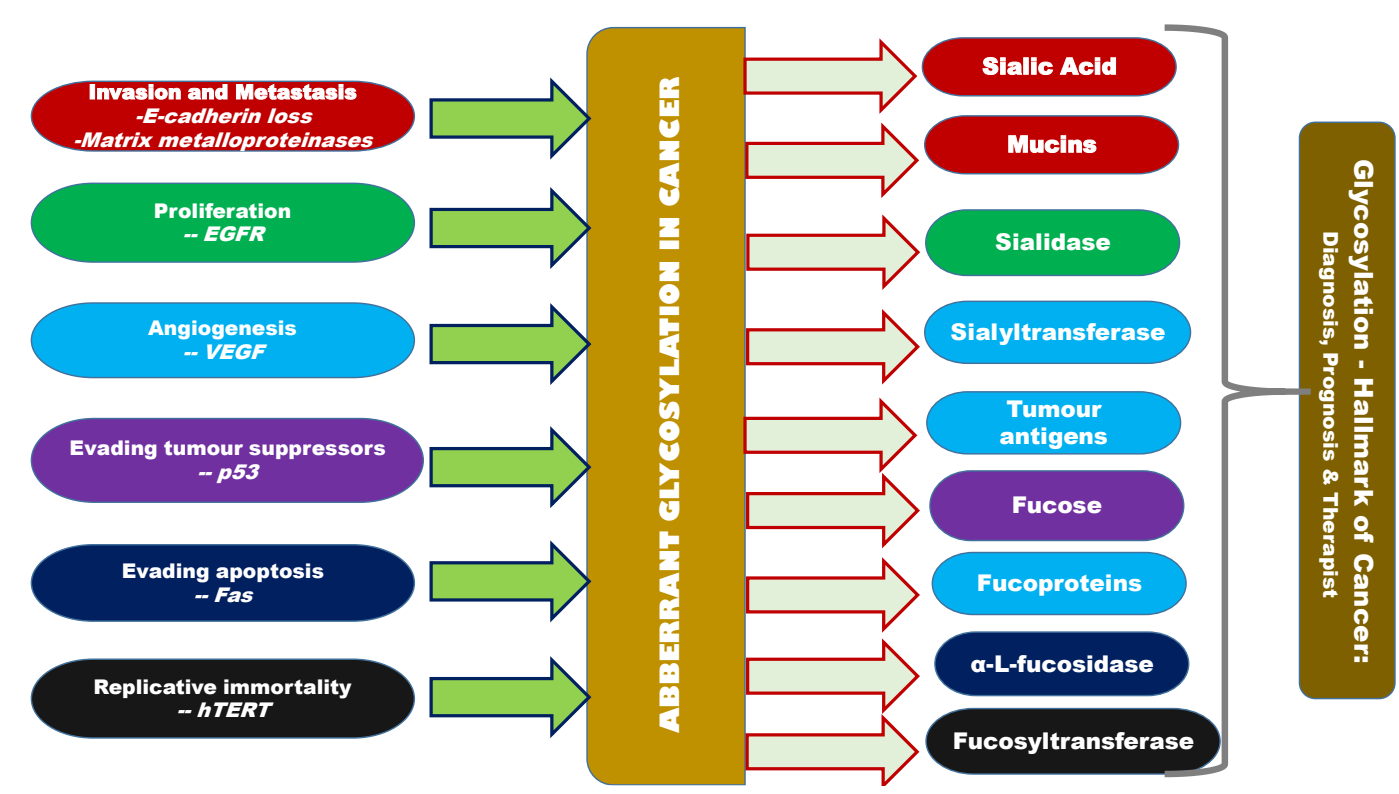

Figure 2. Overview of aberrant glycosylation and its correlation with other hallmarks of cancer, altered expression of sialic acid, siayltransferase, sialidase, sialoproteins, fucose, fucoprotein, fucosidase, fucosyltransferase, mannose and galactose inter-correlated with cancer hallmarks like invasion, metastasis, proliferation, angiogenesis, evasion of growth suppressors, apoptosis, and replicative immortality.

\section{Futuristic Challenges for Glycosylation in Cancers and Conclusions}

As evidenced in the previous section, glycosylation has come a long way in cancer diagnosis, prognosis and therapy. However, there are evident challenges facing the future of glycosylation in cancer. Single biomarkers with moderate sensitivity and specificity for the most common cancers are yet to be identified and some biomarkers are ineffective for the early detection of cancer. Well-designed clinical validation is a prerequisite before clinical application. Bioinformatic approaches and advanced Artificial intelligence (AI) algorithms need to be applied to gain significant progress. Although there are a large number of bioinformatics resources for glycosylation research, almost nothing has been utilized towards glycosylation in cancer. The glycobiomarkers need more clinical validation before they capture the attention of major industry players. The process of validation has been very slow due to lack of suitable high-throughput tools, that are still under development. In the past few years there has been a growing concern that no single biomarker can be reliably used for cancer diagnosis. Further improvements with specific glycan binding receptors and multiplexed assays with computer-assisted pattern analysis is needed in glycobiosensor research for breakthroughs in cancer biomarker discovery [163]. Such integrated and combined approaches are needed in order 
to see progress in this area of research. A coalescence of all three "omics" technologies can result in the integration of protein, gene, and glycan biomarkers into multiplexed platforms, yielding viable cancer diagnostic platforms. In terms of analytical upgrading, the target of pertinent cancer-specific glycosylation as well as lectin-based capture is crucial for detection. It is strangely interesting to add here that although nanoplatforms have been able to push the detection limits and overcome sensitivity limitations, nothing much has been done to involve the nano aspects of this area. Most of the analytical work on glycosylation and cancer reported thus far are all surrounding traditional MS and a handful of MS variants only, and none include the upgraded nano-MS variants. This appears to be a sort of saturation in the research area and a lack of enthusiasm. This is a cross-disciplinary field involving analytical chemists and biologist as well as medical expertise, and is speculated to be the core reason for these broken links.

Cutting-edge achievements of techniques including MS, CE, UPLC, which focus on glycomics as well as lectin-based glyco-capture, microarray and microfluidics which focus on aberrantly glycosylated glycoproteins, have greatly accelerated the discovery and application potentialities of glycomics and glycoprotein markers in various cancers. However, it is too early now to expect that these analytical methods can deliver the anticipated glyco-biomarker revolution. Nano-integrated analytical instrumentation being the current state-of-the-art technology, will no doubt push the analytical limits towards some positive progress. This review brings to notice that none of the nano-analytical platforms have been applied to glycosylation research in the area of cancer. As in all areas of science, the rise of nano has created plenty of room for this, and there is no doubt there is much scope for enhancing glycobiological research through successful application. Maybe, nano is that what is needed to take glycosylation from benchside to bedside.

The success of future glycodiagnostics depends on the availability of new and improved nano-based glycan-binding probes. Most of today's cancer biomarkers are proteins that are glycosylated, but as it is, they lack the sensitivity and most importantly specificity for early detection and therefore are currently not recommended for early detection. Their use is limited for prognosis [164] Except for a handful ( 4) of clinical trials [162], the practical implementation of even the FDA-approved biomarkers has not been initialized. After all, it is apparent that there may be a long and challenging journey from the bench to the clinic for the glycobiomarker discovery according to Wang et al. 2019. Thus, these "sweet" molecules, with complicated physiological and pathological implications hold promising diagnostic, prognostic and therapeutic applications for the future institutional and industrial collaborations. Translation of any biological discovery to clinical applications requires a multidisciplinary team of biologists, chemists, physicists, engineers, and computer experts. This integration of skills is not found in every other organization, so successful clinical progress can only result from interactions of such an interdisciplinary expert collaboration. This review draws attention to the need for such an integrated approach to break the limitations that glycosylation research has hit in the area of cancer biomarker discovery $[74,165-168]$ and to achieve progress.

Author Contributions: Conceptualization, writing-original draft preparation, M.M., J.G., J.-W.O.; writing-review and editing, S.C., A.J.P.D.; funding acquisition, J.-W.O. All authors have read and agreed to the published version of the manuscript.

Funding: This study was supported by grants awarded to JWO (NRF-S201801S00057 and NRF-2020R1F1A1051041) by the Basic Science Research Program through the National Research Foundation of Korea (NRF), funded by the Ministry of Education, Science and Technology.

Conflicts of Interest: The authors declare no conflict of interest. 


\section{References}

1. Berry, L.L.; Davis, S.W.; Flynn, A.G.; Landercasper, J.; Deming, K.A. Is it time to reconsider the term "cancer survivor"? J. Psychosoc. Oncol. 2019, 37, 413-426. [CrossRef]

2. Weaver, K.E.; Forsythe, L.P.; Reeve, B.B.; Alfano, C.M.; Rodriguez, J.L.; Sabatino, S.A.; Hawkins, N.A.; Rowland, J.H. Mental and Physical Health-Related Quality of Life among U.S. Cancer Survivors: Population Estimates from the 2010 National Health Interview Survey. Cancer Epidemiol. Biomark. Prev. 2012, 21, 2108-2117. [CrossRef]

3. Siegel, R.L.; Miller, K.D.; Jemal, A. Cancer statistics, 2019. CA Cancer J. Clin. 2019, 69, 7-34. [CrossRef]

4. Parkin, D.M.; Pisani, P.; Ferlay, J. Global cancer statistics. CA Cancer J. Clin. 1999, 49, 33-64. [CrossRef]

5. Greenlee, R.T.; Murray, T.; Bolden, S.; Wingo, P.A. Cancer statistics, 2000. CA Cancer J. Clin. 2000, 50, 7-33. [CrossRef]

6. Strimbu, K.; Tavel, J.A. What are biomarkers? Curr. Opin. HIV AIDS 2010, 5, 463-466. [CrossRef]

7. Sharon, N. Lectins: Carbohydrate-specific Reagents and Biological Recognition Molecules. J. Biol. Chem. 2007, 282, 2753-2764. [CrossRef]

8. Janković, M. Glycans as Biomarkers: Status and Perspectives. J. Med Biochem. 2011, 30, 213-223. [CrossRef]

9. Schwarz, F.; Aebi, M. Mechanisms and principles of N-linked protein glycosylation. Curr. Opin. Struct. Biol. 2011, 21, 576-582. [CrossRef]

10. Kudelka, M.R.; Ju, T.; Heimburg-Molinaro, J.; Cummings, R.D. Simple Sugars to Complex Disease-Mucin-Type O-Glycans in Cancer. Adv. Cancer Res. 2015, 126, 53-135. [CrossRef]

11. Marth, J.D.; Grewal, P.K. Mammalian glycosylation in immunity. Nat. Rev. Immunol. 2008, 8, 874-887. [CrossRef]

12. Hart, G.W.; Copeland, R.J. Glycomics Hits the Big Time. Cell 2010, 143, 672-676. [CrossRef]

13. Vliegenthart, J.F. The impact of defining glycan structures. Perspect. Sci. 2017, 11, 3-10. [CrossRef]

14. Wang, M.; Zhu, J.; Lubman, D.M.; Gao, C. Aberrant glycosylation and cancer biomarker discovery: A promising and thorny journey. Clin. Chem. Lab. Med. 2019, 57, 407-416. [CrossRef]

15. Krishnan, S.; Whitwell, H.J.; Cuenco, J.; Gentry-Maharaj, A.; Menon, U.; Pereira, S.P.; Gaspari, M.; Timms, J.F. Evidence of Altered Glycosylation of Serum Proteins Prior to Pancreatic Cancer Diagnosis. Int. J. Mol. Sci. 2017, 18, 2670. [CrossRef]

16. Tanabe, K.; Kitagawa, K.; Kojima, N.; Iijima, S. Multifucosylated Alpha-1-acid Glycoprotein as a Novel Marker for Hepatocellular Carcinoma. J. Proteome Res. 2016, 15, 2935-2944. [CrossRef]

17. Pompach, P.; Brnakova, Z.; Sanda, M.; Wu, J.; Edwards, N.; Goldman, R. Site-specific Glycoforms of Haptoglobin in Liver Cirrhosis and Hepatocellular Carcinoma. Mol. Cell. Proteom. 2013, 12, 1281-1293. [CrossRef]

18. Sanda, M.; Pompach, P.; Brnakova, Z.; Wu, J.; Makambi, K.; Goldman, R. Quantitative Liquid Chromatography-Mass Spectrometry-Multiple Reaction Monitoring (LC-MS-MRM) Analysis of Site-specific Glycoforms of Haptoglobin in Liver Disease. Mol. Cell. Proteom. 2013, 12, 1294-1305. [CrossRef]

19. Chandler, K.B.; Pompach, P.; Goldman, R.; Edwards, N. Exploring Site-Specific N-Glycosylation Microheterogeneity of Haptoglobin Using Glycopeptide CID Tandem Mass Spectra and Glycan Database Search. J. Proteome Res. 2013, 12, 3652-3666. [CrossRef]

20. Ren, S.; Zhang, Z.; Xu, C.; Guo, L.; Lu, R.; Sun, Y.; Guo, J.; Qin, R.; Qin, W.; Gu, J. Distribution of IgG galactosylation as a promising biomarker for cancer screening in multiple cancer types. Cell Res. 2016, 26, 963-966. [CrossRef]

21. Zhang, Y.; Zhu, J.; Yin, H.; Marrero, J.A.; Zhang, X.-X.; Lubman, D.M. ESI-LC-MS Method for Haptoglobin Fucosylation Analysis in Hepatocellular Carcinoma and Liver Cirrhosis. J. Proteome Res. 2015, 14, 5388-5395. [CrossRef]

22. Lin, Z.; Yin, H.; Lo, A.; Ruffin, M.T.; Anderson, M.A.; Simeone, D.M.; Lubman, D.M. Label-free relative quantification of alpha-2-macroglobulin site-specific core-fucosylation in pancreatic cancer by LC-MS/MS. Electrophoresis 2013, 35, 2108-2115. [CrossRef]

23. Yin, H.; Lin, Z.; Nie, S.; Wu, J.; Tan, Z.; Zhu, J.; Dai, J.; Feng, Z.; Marrero, J.; Lubman, D.M. Mass-Selected Site-Specific Core-Fucosylation of Ceruloplasmin in Alcohol-Related Hepatocellular Carcinoma. J. Proteome Res. 2014, 13, 2887-2896. [CrossRef] 
24. Gbormittah, F.O.; Bones, J.; Hincapie, M.; Tousi, F.; Hancock, W.S.; Iliopoulos, O. Clusterin Glycopeptide Variant Characterization Reveals Significant Site-Specific Glycan Changes in the Plasma of Clear Cell Renal Cell Carcinoma. J. Proteome Res. 2015, 14, 2425-2436. [CrossRef]

25. Song, T.; Aldredge, D.; Lebrilla, C.B. A Method for In-Depth Structural Annotation of Human Serum Glycans That Yields Biological Variations. Anal. Chem. 2015, 87, 7754-7762. [CrossRef]

26. Hamid, U.M.A.; Royle, L.; Saldova, R.; Radcliffe, C.M.; Harvey, D.J.; Storr, S.J.; Pardo, M.; Antrobus, R.; Chapman, C.J.; Zitzmann, N.; et al. A strategy to reveal potential glycan markers from serum glycoproteins associated with breast cancer progression. Glycobiology 2008, 18, 1105-1118. [CrossRef]

27. Chen, B.; Zhong, X.; Feng, Y.; Snovida, S.; Xu, M.; Rogers, J.; Li, L. Targeted MultiNotch MS3 Approach for Relative Quantification of N-Glycans Using Multiplexed Carbonyl-Reactive Isobaric Tags. Anal. Chem. 2017, 90, 1129-1135. [CrossRef]

28. Rho, J.-H.; Mead, J.R.; Wright, W.S.; Brenner, D.E.; Stave, J.W.; Gildersleeve, J.C.; Lampe, P. Discovery of sialyl Lewis A and Lewis $\mathrm{X}$ modified protein cancer biomarkers using high density antibody arrays. J. Proteom. 2014, 96, 291-299. [CrossRef]

29. Mayampurath, A.; Song, E.; Mathur, A.; Yu, C.-Y.; Hammoud, Z.; Mechref, Y.; Tang, H. Label-Free Glycopeptide Quantification for Biomarker Discovery in Human Sera. J. Proteome Res. 2014, 13, 4821-4832. [CrossRef]

30. Gebrehiwot, A.G.; Melka, D.S.; Kassaye, Y.M.; Rehan, I.F.; Rangappa, S.; Hinou, H.; Kamiyama, T.; Nishimura, S.-I. Healthy human serum N-glycan profiling reveals the influence of ethnic variation on the identified cancer-relevant glycan biomarkers. PLOS ONE 2018, 13, e0209515. [CrossRef]

31. Zhu, J.; Lin, Z.; Wu, J.; Yin, H.; Dai, J.; Feng, Z.; Marrero, J.; Lubman, D.M. Analysis of Serum Haptoglobin Fucosylation in Hepatocellular Carcinoma and Liver Cirrhosis of Different Etiologies. J. Proteome Res. 2014, 13, 2986-2997. [CrossRef]

32. Nakagawa, T.; Miyoshi, E.; Yakushijin, T.; Hiramatsu, N.; Igura, T.; Hayashi, N.; Taniguchi, N.; Kondo, A. Glycomic Analysis of Alpha-Fetoprotein L3 in Hepatoma Cell Lines and Hepatocellular Carcinoma Patients. J. Proteome Res. 2008, 7, 2222-2233. [CrossRef]

33. Mittermayr, S.; Bones, J.; Doherty, M.; Guttman, A.; Rudd, P.M. Multiplexed Analytical Glycomics: Rapid and Confident IgGN-Glycan Structural Elucidation. J. Proteome Res. 2011, 10, 3820-3829. [CrossRef]

34. Saldova, R.; Shehni, A.A.; Haakensen, V.D.; Steinfeld, I.; Hilliard, M.; Kifer, I.; Helland, Å.; Yakhini, Z.; Børresen-Dale, A.-L.; Rudd, P.M. Association of N-Glycosylation with Breast Carcinoma and Systemic Features Using High-Resolution Quantitative UPLC. J. Proteome Res. 2014, 13, 2314-2327. [CrossRef]

35. Knezevic, A.; Bones, J.; Kračun, S.K.; Gornik, O.; Rudd, P.M.; Lauc, G. High throughput plasma N-glycome profiling using multiplexed labelling and UPLC with fluorescence detection. Analyst 2011, 136, 4670-4673. [CrossRef]

36. Callewaert, N.; Geysens, S.; Molemans, F.; Contreras, R. Ultrasensitive profiling and sequencing of N-linked oligosaccharides using standard DNA-sequencing equipment. Glycobiology 2001, 11, 275-281. [CrossRef]

37. Laroy, W.; Contreras, R.; Callewaert, N. Glycome mapping on DNA sequencing equipment. Nat. Protoc. 2006, 1, 397-405. [CrossRef]

38. Vermassen, T.; Van Praet, C.; Vanderschaeghe, D.; Maenhout, T.; Lumen, N.; Callewaert, N.; Hoebeke, P.; Van Belle, S.; Rottey, S.; Delanghe, J.R. Capillary electrophoresis of urinary prostate glycoproteins assists in the diagnosis of prostate cancer. Electrophoresis 2013, 35, 1017-1024. [CrossRef]

39. Verhelst, X.; Vanderschaeghe, D.; Castéra, L.; Raes, T.; Geerts, A.; Francoz, C.; Colman, R.; Durand, F.; Callewaert, N.; Van Vlierberghe, H. A Glycomics-Based Test Predicts the Development of Hepatocellular Carcinoma in Cirrhosis. Clin. Cancer Res. 2017, 23, 2750-2758. [CrossRef]

40. Callewaert, N.; Van Vlierberghe, H.; Van Hecke, A.; Laroy, W.; Delanghe, J.; Contreras, R. Noninvasive diagnosis of liver cirrhosis using DNA sequencer-based total serum protein glycomics. Nat. Med. 2004, 10, 429-434. [CrossRef]

41. Debruyne, E.N.; Vanderschaeghe, D.; Van Vlierberghe, H.; Vanhecke, A.; Callewaert, N.; Delanghe, J. Diagnostic Value of the Hemopexin N-Glycan Profile in Hepatocellular Carcinoma Patients. Clin. Chem. 2010, 56, 823-831. [CrossRef]

42. Fang, M.; Zhao, Y.-P.; Zhou, F.-G.; Lu, L.-G.; Qi, P.; Wang, H.; Zhou, K.; Sun, S.-H.; Chen, C.-Y.; Gao, C.-F. $\mathrm{N}$-glycan based models improve diagnostic efficacies in hepatitis B virus-related hepatocellular carcinoma. Int. J. Cancer 2009, 127, 148-159. [CrossRef] 
43. Zhao, Y.-P.; Ruan, C.; Wang, H.; Hu, Z.-Q.; Fang, M.; Gu, X.; Ji, J.; Zhao, J.-Y.; Gao, C.-F. Identification and assessment of new biomarkers for colorectal cancer with serum N-glycan profiling. Cancer 2011, 118, 639-650. [CrossRef]

44. Chen, J.; Fang, M.; Zhao, Y.-P.; Yi, C.-H.; Ji, J.; Cheng, C.; Wang, M.-M.; Gu, X.; Sun, Q.-S.; Chen, X.-L.; et al. Serum N-Glycans: A New Diagnostic Biomarker for Light Chain Multiple Myeloma. PLoS ONE 2015, 10, e0127022. [CrossRef]

45. Wang, M.; Fang, M.; Zhu, J.; Feng, H.; Warner, E.; Yi, C.; Ji, J.; Gu, X.; Gao, C. Serum N -glycans outperform CA19-9 in diagnosis of extrahepatic cholangiocarcinoma. Electrophoresis 2017, 38, 2749-2756. [CrossRef]

46. Zhao, Y.-P.; Xu, X.-Y.; Fang, M.; Wang, H.; You, Q.; Yi, C.-H.; Ji, J.; Gu, X.; Zhou, P.-T.; Cheng, C.; et al. Decreased Core-Fucosylation Contributes to Malignancy in Gastric Cancer. PLoS ONE 2014, 9, e94536. [CrossRef]

47. Yang, H.-F.; Yu, M.; Jin, H.-D.; Yao, J.-Q.; Lu, Z.-L.; Yabasin, I.B.; Yan, Q.; Wen, Q. Fentanyl Promotes Breast Cancer Cell Stemness and Epithelial-Mesenchymal Transition by Upregulating $\alpha 1,6$-Fucosylation via Wnt/ $\beta$-Catenin Signaling Pathway. Front. Physiol. 2017, 8, 510. [CrossRef]

48. Tu, C.-F.; Wu, M.-Y.; Lin, Y.-C.; Kannagi, R.; Yang, R.-B. FUT8 promotes breast cancer cell invasiveness by remodeling TGF- $\beta$ receptor core fucosylation. Breast Cancer Res. 2017, 19, 1-15. [CrossRef]

49. Matsuda, A.; Higashi, M.; Nakagawa, T.; Yokoyama, S.; Kuno, A.; Yonezawa, S.; Narimatsu, H. Assessment of tumor characteristics based on glycoform analysis of membrane tethered MUC1. Lab. Investig. 2017, 97, 1103-1113. [CrossRef]

50. Yi, C.-H.; Weng, H.-L.; Zhou, F.-G.; Fang, M.; Ji, J.; Cheng, C.; Wang, H.; Liebe, R.; Dooley, S.; Gao, C.-F. Elevated core-fucosylated IgG is a new marker for hepatitis B virus-related hepatocellular carcinoma. OncoImmunology 2015, 4, e1011503. [CrossRef]

51. Zhang, S.; Jiang, K.; Zhang, Q.; Guo, K.; Liu, Y. Serum fucosylated paraoxonase 1 as a potential glycobiomarker for clinical diagnosis of early hepatocellular carcinoma using ELISA Index. Glycoconj. J. 2015, 32, 119-125. [CrossRef]

52. Li, L.; Gu, X.; Fang, M.; Ji, J.; Yi, C.; Gao, C. The diagnostic value of serum fucosylated fetuin A in hepatitis B virus-related liver diseases. Clin. Chem. Lab. Med. 2016, 54, 693-701. [CrossRef]

53. Wu, J.; Zhu, J.; Yin, H.; Buckanovich, R.J.; Lubman, D.M. Analysis of Glycan Variation on Glycoproteins from Serum by the Reverse Lectin-Based ELISA Assay. J. Proteome Res. 2014, 13, 2197-2204. [CrossRef]

54. Song, E.; Zhu, R.; Hammoud, Z.T.; Mechref, Y. LC-MS/MS Quantitation of Esophagus Disease Blood Serum Glycoproteins by Enrichment with Hydrazide Chemistry and Lectin Affinity Chromatography. J. Proteome Res. 2014, 13, 4808-4820. [CrossRef]

55. Fanayan, S.; Hincapie, M.; Hancock, W.S. Using lectins to harvest the plasma/serum glycoproteome. Electrophoresis 2012, 33, 1746-1754. [CrossRef]

56. Syed, P.; Gidwani, K.; Kekki, H.; Leivo, J.; Pettersson, K.; Lamminmäki, U. Role of lectin microarrays in cancer diagnosis. Proteomics 2016, 16, 1257-1265. [CrossRef]

57. Matsuda, A.; Kuno, A.; Nakagawa, T.; Ikehara, Y.; Irimura, T.; Yamamoto, M.; Nakanuma, Y.; Miyoshi, E.; Nakamori, S.; Nakanishi, H.; et al. Lectin Microarray-Based Sero-Biomarker Verification Targeting AberrantO-Linked Glycosylation on Mucin 1. Anal. Chem. 2015, 87, 7274-7281. [CrossRef]

58. Hirabayashi, J.; Yamada, M.; Kuno, A.; Tateno, H. Lectin microarrays: Concept, principle and applications. Chem. Soc. Rev. 2013, 42, 4443-4458. [CrossRef]

59. Shang, Y.; Zeng, Y.; Zeng, Y. Integrated Microfluidic Lectin Barcode Platform for High-Performance Focused Glycomic Profiling. Sci. Rep. 2016, 6, 20297. [CrossRef]

60. Haab, B.B. Antibody-lectin sandwich arrays for biomarker and glycobiology studies. Expert Rev. Proteom. 2010, 7, 9-11. [CrossRef]

61. Kletter, D.; Curnutte, B.; Maupin, K.A.; Bern, M.; Haab, B.B. Exploring the Specificities of Glycan-Binding Proteins Using Glycan Array Data and the GlycoSearch Software. Methods Mol. Biol. 2015, 1273, $203-214$. [CrossRef]

62. Patwa, T.; Li, C.; Simeone, D.M.; Lubman, D.M. Glycoprotein analysis using protein microarrays and mass spectrometry. Mass Spectrom. Rev. 2010, 29, 830-844. [CrossRef]

63. Agre, P.; Bertozzi, C.; Bissell, M.; Campbell, K.P.; Cummings, R.D.; Desai, U.R.; Estes, M.; Flotte, T.; Fogleman, G.; Gage, F.; et al. Training the next generation of biomedical investigators in glycosciences. J. Clin. Investig. 2016, 126, 405-408. [CrossRef] 
64. Wu, J.; Xie, X.; Nie, S.; Buckanovich, R.J.; Lubman, D.M. Altered Expression of Sialylated Glycoproteins in Ovarian Cancer Sera Using Lectin-based ELISA Assay and Quantitative Glycoproteomics Analysis. J. Proteome Res. 2013, 12, 3342-3352. [CrossRef]

65. Paulson, J.C.; Colley, K.J. Glycosyltransferases. Structure, localization, and control of cell type-specific glycosylation. J. Biol. Chem. 1989, 264, 17615-17618.

66. Dube, D.H.; Bertozzi, C.R. Glycans in cancer and inflammation-Potential for therapeutics and diagnostics. Nat. Rev. Drug Discov. 2005, 4, 477-488. [CrossRef]

67. Hakomori, S. Tumor malignancy defined by aberrant glycosylation and sphingo(glyco)lipid metabolism. Cancer Res. 1996, 56, 5309-5318.

68. Taylor, A.D.; Hancock, W.S.; Hincapie, M.; Taniguchi, N.; Hanash, S.M. Towards an integrated proteomic and glycomic approach to finding cancer biomarkers. Genome Med. 2009, 1, 1-10. [CrossRef]

69. Yamamoto, H.; Swoger, J.; Greene, S.; Saito, T.; Hurh, J.; Sweeley, C.; Leestma, J.; Mkrdichian, E.; Cerullo, L.; Nishikawa, A.; et al. Beta1,6-N-acetylglucosamine-bearing N-glycans in human gliomas: Implications for a role in regulating invasivity. Cancer Res. 2000, 60, 134-142.

70. Couldrey, C.; Green, J. Jeffrey, E. Metastases: The glycan connection. Breast Cancer Res. 2000, 2, 321-323. [CrossRef]

71. Taniguchi, N.; Ihara, S.; Saito, T.; Miyoshi, E.; Ikeda, Y.; Honke, K. Implication of GnT-V in cancer metastasis: A glycomic approach for identification of a target protein and its unique function as an angiogenic cofactor. Glycoconj. J. 2001, 18, 859-865. [CrossRef]

72. Demetriou, M.; Nabi, I.R.; Coppolino, M.; Dedhar, S.; Dennis, J.W. Reduced contact-inhibition and substratum adhesion in epithelial cells expressing GlcNAc-transferase V. J. Cell Biol. 1995, 130, 383-392. [CrossRef]

73. Munkley, J. The Role of Sialyl-Tn in Cancer. Int. J. Mol. Sci. 2016, 17, 275. [CrossRef]

74. Munkley, J.; Elliott, D.J. Hallmarks of glycosylation in cancer. Oncotarget 2016, 7, 35478-35489. [CrossRef]

75. Tuccillo, F.M.; De Laurentiis, A.; Palmieri, C.; Fiume, G.; Bonelli, P.; Borrelli, A.; Tassone, P.; Scala, I.; Buonaguro, F.M.; Quinto, I.; et al. Aberrant Glycosylation as Biomarker for Cancer: Focus on CD43. BioMed Res. Int. 2014, 2014, 1-13. [CrossRef]

76. Yin, B.W.; Dnistrian, A.; Lloyd, K.O. Ovarian cancer antigen CA125 is encoded by theMUC16 mucin gene. Int. J. Cancer 2002, 98, 737-740. [CrossRef]

77. O’Brien, T.J.; Beard, J.B.; Underwood, L.J.; Dennis, R.A.; Santin, A.D.; York, L. The CA 125 Gene: An Extracellular Superstructure Dominated by Repeat Sequences. Tumor Biol. 2001, 22, 348-366. [CrossRef]

78. Nustad, K.; Bast, J.R.; O’Brien, T.; Nilsson, O.; Seguin, P.; Suresh, M.R.; Saga, T.; Nozawa, S.; Børmer, O.P.; De Bruijn, H.; et al. Specificity and Affinity of 26 Monoclonal Antibodies against the CA 125 Antigen: First Report from the ISOBM TD-1 Workshop. Tumor Biol. 1996, 17, 196-219. [CrossRef]

79. Yin, B.W.T.; Lloyd, K.O. Molecular Cloning of the CA125 Ovarian Cancer Antigen. J. Biol. Chem. 2001, 276, 27371-27375. [CrossRef]

80. Zurawski, V.R.; Orjaseter, H.; Andersen, A.; Jellum, E. Elevated serum CA 125 levels prior to diagnosis of ovarian neoplasia: Relevance for early detection of ovarian cancer. Int. J. Cancer 1988, 42, 677-680. [CrossRef]

81. Bast, R.C.; Klug, T.L.; John, E.S.; Jenison, E.; Niloff, J.M.; Lazarus, H.; Berkowitz, R.S.; Leavitt, T.; Griffiths, C.T.; Parker, L.; et al. A Radioimmunoassay Using a Monoclonal Antibody to Monitor the Course of Epithelial Ovarian Cancer. N. Engl. J. Med. 1983, 309, 883-887. [CrossRef]

82. Bast, R.C.; Badgwell, D.; Lu, Z.; Marquez, R.; Rosen, D.; Liu, J.; Baggerly, K.; Atkinson, E.; Skates, S.; Zhang, Z.; et al. New tumor markers: CA125 and beyond. Int. J. Gynecol. Cancer 2005, 15, 274-281. [CrossRef]

83. Gostout, B.S.; Brewer, M.A. Guidelines for Referral of the Patient with an Adnexal Mass. Clin. Obstet. Gynecol. 2006, 49, 448-458. [CrossRef]

84. Pauler, D.K.; Menon, U.; McIntosh, M.; Symecko, H.L.; Skates, S.J.; Jacobs, I.J. Factors influencing serum CA125II levels in healthy postmenopausal women. Cancer Epidemiol. Biomark. Prev. 2001, 10, 489-493.

85. Lauro, S.; Trasatti, L.; Bordin, F.; Lanzetta, G.; Bria, E.; Gelibter, A.; Reale, M.G.; Vecchione, A. Comparison of CEA, MCA, CA 15-3 and CA 27-29 in follow-up and monitoring therapeutic response in breast cancer patients. Anticancer Res. 2000, 19, 3511-3515.

86. Uehara, M.; Kinoshita, T.; Hojo, T.; Akashi-Tanaka, S.; Iwamoto, E.; Fukutomi, T. Long-term prognostic study of carcinoembryonic antigen (CEA) and carbohydrate antigen 15-3 (CA 15-3) in breast cancer. Int. J. Clin. Oncol. 2008, 13, 447-451. [CrossRef] 
87. Kumpulainen, E.J.; Keskikuru, R.J.; Johansson, R.T. Serum Tumor Marker CA 15.3 and Stage are the Two Most Powerful Predictors of Survival in Primary Breast Cancer. Breast Cancer Res. Treat. 2002, 76, 95-102. [CrossRef]

88. Ebeling, F.G.; Stieber, P.; Untch, M.; Nagel, D.; Konecny, G.E.; Schmitt, U.M.; Fateh-Moghadam, A.; Seidel, D. Serum CEA and CA 15-3 as prognostic factors in primary breast cancer. Br. J. Cancer 2002, 86, 1217-1222. [CrossRef]

89. Harris, L.; Fritsche, H.; Mennel, R.; Norton, L.; Ravdin, P.; Taube, S.; Somerfield, M.R.; Hayes, D.F.; Bast, R.C., Jr. American society of clinical oncology 2007 update of recommendations for the use of tumor markers in breast cancer. J. Clin. Oncol. 2007, 25, 5287-5312. [CrossRef]

90. Locker, G.Y.; Hamilton, S.; Harris, J.; Jessup, J.M.; Kemeny, N.; Macdonald, J.S.; Somerfield, M.R.; Hayes, D.F.; Bast, R.C., Jr. ASCO 2006 Update of Recommendations for the Use of Tumor Markers in Gastrointestinal Cancer. J. Clin. Oncol. 2006, 24, 5313-5327. [CrossRef]

91. Safi, F. Diagnostic value of CA 19-9 in patients with pancreatic cancer and nonspecific gastrointestinal symptoms. J. Gastrointest. Surg. 1997, 1, 106-112. [CrossRef]

92. Ychou, M.; Duffour, J.; Kramar, A.; Gourgou, S.; Grenier, J. Clinical Significance and Prognostic Value of CA72-4 Compared with CEA and CA19-9 in Patients with Gastric Cancer. Dis. Markers 2000, 16, 105-110. [CrossRef]

93. Marrelli, D.; Pinto, E.; De Stefano, A.; De Manzoni, G.; Farnetani, M.; Garosi, L.; Roviello, F. Preoperative positivity of serum tumor markers is a strong predictor of hematogenous recurrence of gastric cancer. J. Surg. Oncol. 2001, 78, 253-258. [CrossRef]

94. Duraker, N.; Çelik, A.N. The prognostic significance of preoperative serum CA 19-9 in patients with resectable gastric carcinoma: Comparison with CEA. J. Surg. Oncol. 2001, 76, 266-271. [CrossRef]

95. Reiter, W.; Stieber, P.; Reuter, C.; Nagel, D.; Cramer, C.; Pahl, H.; Fateh-Moghadam, A. Prognostic value of preoperative serum levels of CEA, CA 19-9 and CA 72-4 in gastric carcinoma. Anticancer Res. 1997, 17, 2903-2906.

96. Mazal, D.; Lo-Man, R.; Bay, S.; Pritsch, O.; Dériaud, E.; Ganneau, C.; Medeiros, A.; Ubillos, L.; Obal, G.; Berois, N.; et al. Monoclonal antibodies toward different Tn-amino acid backbones display distinct recognition patterns on human cancer cells. Implications for effective immuno-targeting of cancer. Cancer Immunol. Immunother. 2013, 62, 1107-1122. [CrossRef]

97. Ju, T.; Wang, Y.; Aryal, R.P.; Lehoux, S.D.; Ding, X.; Kudelka, M.R.; Cutler, C.; Zeng, J.; Wang, J.; Sun, X.; et al. Tn and sialyl-Tn antigens, aberrant $\mathrm{O}$-glycomics as human disease markers. Proteom. Clin. Appl. 2013, 7, 618-631. [CrossRef]

98. Kumar, S.R.; Sauter, E.R.; Quinn, T.P.; Deutscher, S.L. Thomsen-Friedenreich and Tn Antigens in Nipple Fluid: Carbohydrate Biomarkers for Breast Cancer Detection. Clin. Cancer Res. 2005, 11, 6868-6871. [CrossRef]

99. Carpelan-Holmström, M.; Louhimo, J.; Stenman, U.-H.; Alfthan, H.; Järvinen, H.; Haglund, C. Estimating the Probability of Cancer with Several Tumor Markers in Patients with Colorectal Disease. Oncology 2004, 66, 296-302. [CrossRef]

100. Springer, G.F. Immunoreactive $\mathrm{T}$ and Tn epitopes in cancer diagnosis, prognosis, and immunotherapy. J. Mol. Med. 1997, 75, 594-602. [CrossRef]

101. Kjeldsen, T.; Clausen, H.; Hirohashi, S.; Ogawa, T.; Iijima, H.; Hakomori, S. Preparation and characterization of monoclonal antibodies directed to the tumor-associated O-linked sialosyl-2 $\rightarrow 6$ alpha-N-acetylgalactosaminyl (sialosyl-Tn) epitope. Cancer Res. 1988, 48, 2214-2220.

102. Hamazoe, R.; Maeta, M.; Matsui, T.; Shibata, S.; Shiota, S.; Kaibara, N. CA72-4 compared with carcinoembryonic antigen as a tumour marker for gastric cancer. Eur. J. Cancer 1992, 28, 1351-1354. [CrossRef]

103. Louhimo, J.; Alfthan, H.; Stenman, U.-H.; Haglund, C. Serum HCG? and CA 72-4 Are Stronger Prognostic Factors than CEA, CA 19-9 and CA 242 in Pancreatic Cancer. Oncology 2004, 66, 126-131. [CrossRef]

104. Sanders, D.S.; Kerr, M.A. Lewis blood group and CEA related antigens; coexpressed cell-cell adhesion molecules with roles in the biological progression and dissemination of tumours. Mol. Pathol. 1999, 52, 174-178. [CrossRef]

105. Ilantzis, C.; DeMarte, L.; Screaton, R.A.; Stanners, C.P. Deregulated Expression of the Human Tumor Marker CEA and CEA Family Member CEACAM6 Disrupts Tissue Architecture and Blocks Colonocyte Differentiation. Neoplasia 2002, 4, 151-163. [CrossRef]

106. Grunnet, M.; Sorensen, J. Carcinoembryonic antigen (CEA) as tumor marker in lung cancer. Lung Cancer 2012, 76, 138-143. [CrossRef] 
107. Haas, M.; Heinemann, V.; Kullmann, F.; Laubender, R.P.; Klose, C.; Bruns, C.J.; Holdenrieder, S.; Modest, D.P.; Schulz, C.; Boeck, S. Prognostic value of CA 19-9, CEA, CRP, LDH and bilirubin levels in locally advanced and metastatic pancreatic cancer: Results from a multicenter, pooled analysis of patients receiving palliative chemotherapy. J. Cancer Res. Clin. Oncol. 2013, 139, 681-689. [CrossRef]

108. Lee, K.J.; Yi, S.W.; Chung, M.J.; Park, S.W.; Song, S.Y.; Chung, J.B.; Park, J.Y. Serum CA 19-9 and CEA Levels as a Prognostic Factor in Pancreatic Adenocarcinoma. Yonsei Med. J. 2013, 54, 643-649. [CrossRef]

109. Munkley, J. The glycosylation landscape of pancreatic cancer (Review). Oncol. Lett. 2019, 17, 2569-2575. [CrossRef]

110. Munkley, J.; Elliott, D.J. Sugars and cell adhesion: The role of ST6GalNAc1 in prostate cancer progression. Cancer Cell Microenviron. 2016, 3. [CrossRef]

111. Munkley, J. Glycosylation is a global target for androgen control in prostate cancer cells. Endocrine-Related Cancer 2017, 24, R49-R64. [CrossRef]

112. Yıld1z, S.Y. Systems Glycobiology: Past, Present, and Future. Comput. Biol. Chem. 2020. [CrossRef]

113. Palmigiano, A.; Barone, R.; Sturiale, L.; Sanfilippo, C.; Bua, R.O.; Romeo, D.A.; Messina, A.; Capuana, M.L.; Maci, T.; Le Pira, F.; et al. CSF N-glycoproteomics for early diagnosis in Alzheimer's disease. J. Proteom. 2016, 131, 29-37. [CrossRef]

114. Brockhausen, I.; Yang, J.-M.; Burchell, J.M.; Whitehouse, C.; Taylor-Papadimitriou, J. Mechanisms Underlying Aberrant Glycosylation of MUC1 Mucin in Breast Cancer Cells. JBIC J. Biol. Inorg. Chem. 1995, 233, 607-617. [CrossRef]

115. Gils, A.; Pedersen, K.E.; Skottrup, P.D.; Christensen, A.; Naessens, D.; Deinum, J.; Enghild, J.J.; Declerck, P.J.; Andreasen, P.A. Biochemical importance of glycosylation of plasminogen activator inhibitor 1. Thromb. Haemost. 2003, 90, 206-217. [CrossRef]

116. Lempiäinen, A.; Hotakainen, K.; Blomqvist, C.; Alfthan, H.; Stenman, U.-H. Hyperglycosylated Human Chorionic Gonadotropin in Serum of Testicular Cancer Patients. Clin. Chem. 2012, 58, 1123-1129. [CrossRef]

117. Sato, Y.; Nakata, K.; Kato, Y.; Shima, M.; Ishii, N.; Koji, T.; Taketa, K.; Endo, Y.; Nagataki, S. Early Recognition of Hepatocellular Carcinoma Based on Altered Profiles of Alpha-Fetoprotein. N. Engl. J. Med. 1993, 328, 1802-1806. [CrossRef]

118. Gadroy, P.; Stridsberg, M.; Capon, C.; Michalski, J.-C.; Strub, J.-M.; Van Dorsselaer, A.; Aunis, M.; Metz-Boutigue, M.-H. Phosphorylation and O-glycosylation sites of human chromogranin A (CGA79-439) from urine of patients with carcinoid tumors. J. Biol. Chem. 1998, 273, 34087-34097. [CrossRef]

119. Janković, M.; Milutinovic, B.S. Glycoforms of CA125 antigen as a possible cancer marker. Cancer Biomark. 2008, 4, 35-42. [CrossRef]

120. Hua, L.; Liu, Y.; Zhen, S.; Wan, D.; Cao, J.; Gao, X. Expression and biochemical characterization of recombinant human epididymis protein 4. Protein Expr. Purif. 2014, 102, 52-62. [CrossRef]

121. Vajaria, B.N.; Patel, P.S. Glycosylation: A hallmark of cancer? Glycoconj. J. 2017, 34, 147-156. [CrossRef]

122. Venkitachalam, S.; Revoredo, L.; Varadan, V.; Fecteau, R.E.; Ravi, L.; Lutterbaugh, J.; Markowitz, S.D.; Willis, J.E.; Gerken, T.A.; Guda, K. Biochemical and functional characterization of glycosylation-associated mutational landscapes in colon cancer. Sci. Rep. 2016, 6, 23642. [CrossRef]

123. Nadeem, T.; Khan, M.A.; Ijaz, B.; Ahmed, N.; Rahman, Z.U.; Latif, M.S.; Ali, Q.; Rana, M.A. Glycosylation of Recombinant Anticancer Therapeutics in Different Expression Systems with Emerging Technologies. Cancer Res. 2018, 78, 2787-2798. [CrossRef]

124. Bergstrom, K.S.B.; Xia, L. Mucin-type O-glycans and their roles in intestinal homeostasis. Glycobiology 2013, 23, 1026-1037. [CrossRef]

125. Brockhausen, I.; Schachter, H.; Stanley, P. O-GalNAc Glycans. In Essentials of Glycobiology; Varki, A., Cummings, R.D., Esko, J.D., Freeze, H.H., Stanley, P., Bertozzi, C.R., Hart, G.W., Etzler, M.E., Eds.; Cold Spring Harbor: Long Island, NY, USA, 2009.

126. Tran, D.T.; Hagen, K.G.T. Mucin-type O-Glycosylation during Development. J. Biol. Chem. 2013, 288, 6921-6929. [CrossRef]

127. Guda, K.; Veigl, M.L.; Varadan, V.; Nosrati, A.; Ravi, L.; Lutterbaugh, J.; Beard, L.; Willson, J.K.V.; Sedwick, W.D.; Wang, Z.J.; et al. Novel recurrently mutated genes in African American colon cancers. Proc. Natl. Acad. Sci. USA 2015, 112, 1149-1154. [CrossRef]

128. Sjöblom, T.; Jones, S.; Wood, L.D.; Parsons, D.W.; Lin, J.; Barber, T.D.; Mandelker, D.; Leary, R.J.; Ptak, J.; Silliman, N.; et al. The Consensus Coding Sequences of Human Breast and Colorectal Cancers. Science 2006, 314, 268-274. [CrossRef] 
129. Sunyaev, S. Prediction of deleterious human alleles. Hum. Mol. Genet. 2001, 10, 591-597. [CrossRef]

130. Kumar, P.; Henikoff, S.; Ng, P.C. Predicting the effects of coding non-synonymous variants on protein function using the SIFT algorithm. Nat. Protoc. 2009, 4, 1073-1081. [CrossRef]

131. Mitsui, Y.; Yamada, K.; Hara, S.; Kinoshita, M.; Hayakawa, T.; Kakehi, K. Comparative studies on glycoproteins expressing polylactosamine-type N-glycans in cancer cells. J. Pharm. Biomed. Anal. 2012, 70, 718-726. [CrossRef]

132. Togayachi, A.; Kozono, Y.; Kuno, A.; Ohkura, T.; Sato, T.; Hirabayashi, J.; Ikehara, Y.; Narimatsu, H. $\beta 3 G n T 2$ (B3GNT2), a Major Polylactosamine Synthase: Analysis of B3gnt2-Deficient Mice. Methods Enzymol. 2010, 479, 185-204. [CrossRef]

133. Azevedo, R.; Peixoto, A.; Gaiteiro, C.; Fernandes, E.; Neves, M.; Lima, L.; Santos, L.L.; Ferreira, J.A. Over forty years of bladder cancer glycobiology: Where do glycans stand facing precision oncology? Oncotarget 2017, 8, 91734-91764. [CrossRef]

134. Varki, A.; Cummings, R.D.; Esko, J.D.; Freeze, H.H.; Hart, G.W.; Etzler, M.E. Essentials of Glycobiology, 2nd ed.; Cold Spring Harbor Laboratory Press: New York, NY, USA, 2008.

135. Lichtenstein, R.G.; Rabinovich, G.A. Glycobiology of cell death: When glycans and lectins govern cell fate. Cell Death Differ. 2013, 20, 976-986. [CrossRef]

136. Wagner, K.W.; Punnoose, E.; Januario, T.; Lawrence, D.A.; Pitti, R.M.; Lancaster, K.; Lee, D.; Von Goetz, M.; Yee, S.F.; Totpal, K.; et al. Death-receptor O-glycosylation controls tumor-cell sensitivity to the proapoptotic ligand Apo2L/TRAIL. Nat. Med. 2007, 13, 1070-1077. [CrossRef]

137. Moriwaki, K.; Noda, K.; Furukawa, Y.; Ohshima, K.; Uchiyama, A.; Nakagawa, T.; Taniguchi, N.; Daigo, Y.; Nakamura, Y.; Hayashi, N.; et al. Deficiency of GMDS Leads to Escape from NK Cell-Mediated Tumor Surveillance Through Modulation of TRAIL Signaling. Gastroenterology 2009, 137, 188-198.e2. [CrossRef]

138. Dufour, F.; Rattier, T.; Shirley, S.; Picarda, G.; Constantinescu, A.A.; Morlé, A.; Zakaria, A.B.; Marcion, G.; Causse, S.; Szegezdi, E.; et al. N-glycosylation of mouse TRAIL-R and human TRAIL-R1 enhances TRAIL-induced death. Cell Death Differ. 2017, 24, 500-510. [CrossRef]

139. Lima, L.; Severino, P.F.; Silva, M.; Miranda, A.; Tavares, A.; Pereira, S.; Fernandes, E.; Cruz, R.; Amaro, T.; Reis, C.A.; et al. Response of high-risk of recurrence/progression bladder tumours expressing sialyl-Tn and sialyl-6-T to BCG immunotherapy. Br. J. Cancer 2013, 109, 2106-2114. [CrossRef]

140. Cotton, S.; Azevedo, R.; Gaiteiro, C.; Ferreira, D.; Lima, L.; Peixoto, A.; Fernandes, E.; Neves, M.; Neves, D.; Amaro, T.; et al. TargetedO-glycoproteomics explored increased sialylation and identified MUC16 as a poor prognosis biomarker in advanced-stage bladder tumours. Mol. Oncol. 2017, 11, 895-912. [CrossRef]

141. Swindall, A.F.; Bellis, S.L. Sialylation of the Fas Death Receptor by ST6Gal-I Provides Protection against Fas-mediated Apoptosis in Colon Carcinoma Cells. J. Biol. Chem. 2011, 286, 22982-22990. [CrossRef]

142. Shatnyeva, O.M.; Kubarenko, A.V.; Weber, C.E.M.; Pappa, A.; Schwartz-Albiez, R.; Weber, A.N.; Krammer, P.H.; Lavrik, I.N. Modulation of the CD95-Induced Apoptosis: The Role of CD95 N-Glycosylation. PLOS ONE 2011, 6, e19927. [CrossRef]

143. Li, C.; Yang, Z.; Du, Y.; Tang, H.; Chen, J.; Hu, D.; Fan, Z. BCMab1, A Monoclonal Antibody against Aberrantly Glycosylated Integrin 3 1, Has Potent Antitumor Activity of Bladder Cancer In Vivo. Clin. Cancer Res. 2014, 20, 4001-4013. [CrossRef]

144. Santos, S.N.; Junqueira, M.S.; Francisco, G.; Vilanova, M.; Magalhães, A.; Baruffi, M.D.; Chammas, R.; Harris, A.L.; Reis, C.A.; Bernardes, E.S. O-glycan sialylation alters galectin-3 subcellular localization and decreases chemotherapy sensitivity in gastric cancer. Oncotarget 2016, 7, 83570-83587. [CrossRef]

145. Dumic, J.; Dabelic, S.; Flögel, M. Galectin-3: An open-ended story. Biochim. Biophys. Acta (BBA) Gen. Subj. 2006, 1760, 616-635. [CrossRef]

146. Ochieng, J.; Leite-Browning, M.L.; Warfield, P. Regulation of Cellular Adhesion to Extracellular Matrix Proteins by Galectin-3. Biochem. Biophys. Res. Commun. 1998, 246, 788-791. [CrossRef]

147. Liu, F.-T.; Rabinovich, G.A. Galectins as modulators of tumour progression. Nat. Rev. Cancer 2005, 5, 29-41. [CrossRef]

148. Zhuo, Y.; Chammas, R.; Bellis, S.L. Sialylation of 1 Integrins Blocks Cell Adhesion to Galectin-3 and Protects Cells against Galectin-3-induced Apoptosis. J. Biol. Chem. 2008, 283, 22177-22185. [CrossRef]

149. Lempiäinen, A.; Sankila, A.; Hotakainen, K.; Haglund, C.; Blomqvist, C.; Stenman, U.-H. Expression of human chorionic gonadotropin in testicular germ cell tumors. Urol. Oncol. Semin. Orig. Investig. 2014, 32, 727-734. [CrossRef] 
150. Birken, S.; Krichevsky, A.; O'Connor, J.; Schlatterer, J.; Cole, L.; Kardana, A.; Canfield, R. Development and Characterization of Antibodies to a Nicked and Hyperglycosylated Form of HCG from a Choriocarcinoma Patient: Generation of Antibodies That Differentiate between Pregnancy HCG and Choriocarcinoma HCG. Endocrine 1999, 10, 137-144. [CrossRef]

151. Mathupala, S.P.; Rempel, A.; Pedersen, P.L. Glucose Catabolism in Cancer Cells. J. Biol. Chem. 2001, 276, 43407-43412. [CrossRef]

152. Pescador, N.; Villar, D.; Cifuentes, D.; Garcia-Rocha, M.; Ortiz-Barahona, A.; Vazquez, S.; Ordoñez, A.; Cuevas, Y.; Saez-Morales, D.; Garcia-Bermejo, M.L.; et al. Hypoxia Promotes Glycogen Accumulation through Hypoxia Inducible Factor (HIF)-Mediated Induction of Glycogen Synthase 1. PLoS ONE 2010, 5, e9644. [CrossRef]

153. Pelletier, J.; Bellot, G.; Gounon, P.; Lacas-Gervais, S.; Pouysségur, J.; Mazure, N.M. Glycogen Synthesis is Induced in Hypoxia by the Hypoxia-Inducible Factor and Promotes Cancer Cell Survival. Front. Oncol. 2012, 2, 18. [CrossRef]

154. Masson, N.; Ratcliffe, P.J. Hypoxia signaling pathways in cancer metabolism: The importance of co-selecting interconnected physiological pathways. Cancer Metab. 2014, 2, 3. [CrossRef]

155. Ullah, M.S.; Davies, A.J.; Halestrap, A.P. The Plasma Membrane Lactate Transporter MCT4, but Not MCT1, Is Up-regulated by Hypoxia through a HIF-1 $\alpha$-dependent Mechanism. J. Biol. Chem. 2006, 281, 9030-9037. [CrossRef]

156. Chen, Z.; Li, Y.; Zhang, H.; Huang, P.; Luthra, R. Hypoxia-regulated microRNA-210 modulates mitochondrial function and decreases ISCU and COX10 expression. Oncogene 2010, 29, 4362-4368. [CrossRef]

157. Kim, J.-W.; Tchernyshyov, I.; Semenza, G.L.; Dang, C.V.HIF-1-mediated expression of pyruvate dehydrogenase kinase: A metabolic switch required for cellular adaptation to hypoxia. Cell Metab. 2006, 3, 177-185. [CrossRef]

158. Hisanaga, K.; Onodera, H.; Kogure, K. Changes in Levels of Purine and Pyrimidine Nucleotides During Acute Hypoxia and Recovery in Neonatal Rat Brain. J. Neurochem. 1986, 47, 1344-1350. [CrossRef]

159. Yi, W.; Clark, P.M.; Mason, D.E.; Keenan, M.C.; Hill, C.; Goddard, W.A.; Peters, E.C.; Driggers, E.M.; Hsieh-Wilson, L.C. Phosphofructokinase 1 Glycosylation Regulates Cell Growth and Metabolism. Science 2012, 337, 975-980. [CrossRef]

160. Soesanto, Y.A.; Luo, B.; Jones, D.; Taylor, R.; Gabrielsen, J.S.; Parker, G.; McClain, D.A. Regulation of Akt signaling by O-GlcNAc in euglycemia. Am. J. Physiol. Metab. 2008, 295, E974-E980. [CrossRef]

161. Peixoto, A.; Relvas-Santos, M.; Azevedo, R.; Santos, L.L.; Ferreira, J.A. Protein Glycosylation and Tumor Microenvironment Alterations Driving Cancer Hallmarks. Front. Oncol. 2019, 9, 380. [CrossRef]

162. Kirwan, A.; Utratna, M.; O’Dwyer, M.E.; Joshi, L.; Kilcoyne, M. Glycosylation-Based Serum Biomarkers for Cancer Diagnostics and Prognostics. BioMed Res. Int. 2015, 2015, 1-16. [CrossRef]

163. Polanski, M.; Anderson, N.L. A List of Candidate Cancer Biomarkers for Targeted Proteomics. Biomark. Insights 2006, 1, 1-48. [CrossRef]

164. Svarovsky, S.A.; Joshi, L. Cancer glycan biomarkers and their detection-Past, present and future. Anal. Methods 2014, 6, 3918-3936. [CrossRef]

165. Ogino, S.; Chan, A.T.; Fuchs, C.S.; Giovannucci, E. Molecular pathological epidemiology of colorectal neoplasia: An emerging transdisciplinary and interdisciplinary field. Gut 2011, 60, 397-411. [CrossRef]

166. Ogino, S.; Lochhead, P.; Chan, A.T.; Nishihara, R.; Cho, E.; Wolpin, B.M.; Meyerhardt, J.A.; Meissner, A.; Schernhammer, E.S.; Fuchs, C.S.; et al. Molecular pathological epidemiology of epigenetics: Emerging integrative science to analyze environment, host, and disease. Mod. Pathol. 2013, 26, 465-484. [CrossRef]

167. Ogino, S.; Nowak, J.A.; Hamada, T.; Phipps, A.I.; Peters, U., Jr.; Milner, D.A.; Giovannucci, E.L.; Nishihara, R.; Giannakis, M.; Garrett, W.S.; et al. Integrative analysis of exogenous, endogenous, tumour and immune factors for precision medicine. Gut 2018, 67, 1168-1180. [CrossRef]

168. Rodríguez, E.; Schetters, S.T.T.; Van Kooyk, Y. The tumour glyco-code as a novel immune checkpoint for immunotherapy. Nat. Rev. Immunol. 2018, 18, 204-211. [CrossRef]

Publisher's Note: MDPI stays neutral with regard to jurisdictional claims in published maps and institutional affiliations. 